\title{
POCZĄTKI KULTURY PUCHARÓW LEJKOWATYCH NA NIŻU POLSKIM
}

\author{
BEGINNINGS OF THE FUNNEL BEAKER CULTURE \\ IN THE POLISH PLAIN
}

\author{
Stanistaw Kukawka \\ Instytut Archeologii, Uniwersytet Mikołaja Kopernika w Toruniu \\ ul. Szosa Bydgoska 44/48, 87-100 Toruń, Poland \\ stanislaw.kukawka@umk.pl
}

\begin{abstract}
In the article, the author discusses and accepts the need to rejuvenate the chronology of the beginnings of the Funnel Beaker culture in the Polish Plain which should be then dated to about 4200/4100 years BC. While accepting such an approach, the author presents also some of its consequences - e.g. multi-stylistic of pottery and variability of environments inhabited by the earliest Funnel Beaker communities. The article also presents some suggestions concerning the participation of huntergatherers and early agrarian groups in the shaping of this culture in the Polish lowlands. It also raises some questions, which, under the new chronological circumstances, await further archaeometric data and proper discussion.
\end{abstract}

KEY WORDS: Neolithic, Funnel Beaker culture, Polish Plain, chronology.

Chcąc wypowiadać opinie na temat procesów kształtowania się $\mathrm{KPL}^{1}$ na Niżu Polskim, należy rozpoznać sytuację kulturową u jej zarania. Aby to było możliwe, niezbędne jest ustalenie czasu jej początków. W dotychczasowych ujęciach na poglądach badaczy zaważyły przekonania w zakresie typologii naczyń oraz jednostkowe datowanie radiowęglowe z Sarnowa (stan. 1). Aspekt typologiczny sprowadzał się do uznania linearnej w czasie zmienności wyróżniających form ceramiki ${ }^{2}$. Dla naszych rozważań istotne było wydzielenie przez C.J. Beckera na wyspach duńskich

\footnotetext{
${ }^{1} \mathrm{~W}$ tekście zastosowano następujące skróty nazw kultur archeologicznych: KAK - kultura amfor kulistych, KCG - kultura ceramiki grzebykowej, KCWR - kultura ceramiki wstęgowej rytej, KE-E kultura Ertebølle-Ellerbek, KPCW - kultura późnej ceramiki wstęgowej, KPL - kultura pucharów lejkowatych.

${ }^{2}$ Rezultatem takiego myślenia było wydzielenie przez Konrada Jażdżewskiego (1936) fazy wióreckiej i lubońskiej.
} 
i w południowej Szwecji tzw. horyzontu „A” KPL. Miał on być tam starszy od ceramiki typowej dla fazy „B”. Badacz ów zauważając zbliżoną ceramikę na innych terenach i zarazem nie mogąc jej podzielić na dwie odrębne fazy, zaproponował wyodrębnienie „środkowoeuropejskiej fazy A/B” (Becker 1947; Wiślański 1973). Materiały jej odpowiadające znaleziono także we wspomnianym już Sarnowie (stan. 1 i 1A). W 1979 r. T. Wiślański jednoznacznie stwierdził: „nie ulega dziś wątpliwości, że na pozostałych terenach omawianej kultury [poza południową Skandynawią przyp. S. K.] najstarsze dające się wyróżnić stadium stanowią bezwzględnie zespoły typu A/B (sarnowskie)" (Wiślański 1979, s. 175).

W 1968 r. w laboratorium w Groningen wykonano datowanie radiowęglowe próby węgli drzewnych z jamy spod grobowca 8 na stanowisku $1 \mathrm{w}$ Sarnowie. Wiek próby określono na 5570 60 BP (GrN-5035; Bakker, Vogel, Wiślański 1969; Gabałówna 1970). Tak wczesna chronologia materiałów z Sarnowa nie przez wszystkich badaczy i nie do końca była akceptowana. L. Gabałówna komentując ją, podsumowała: „Data sarnowska stanowi najstarsze z dotychczasowych bezwzględnych ustaleń wieku kultury pucharów lejkowatych w Europie. Z pełnym komentarzem tego faktu trzeba jednak poczekać do ukończenia opracowania materiałów z grobowca 8" (Gabałówna 1970, s. 89).

Wśród polskich badaczy ów krytycyzm czy tylko ostrożność nie były bynajmniej powszechne. Datę sarnowską zaakceptował czołowy polski badacz KPL, Konrad Jażdżewski (1970, s. $54^{3}$ ). Zaakceptowali ją też inni badacze neolitu Niżu Polskiego (m.in. L. Czerniak, 1980, 1994; L. Czerniak, Kośko 1993; Kośko 1981; Kukawka 1991; Rzepecki 2004). Akceptacja daty sarnowskiej wynikała, jak sądzę, z trzech przesłanek:

(1) Przekonanie, że zespoły typu „A/B” (fazy sarnowskiej) są bezwzględnie najstarsze $\mathrm{w}$ obrębie KPL sugerowało, iż potencjalne daty radiowęglowe dla tego rodzaju materiałów muszą być wcześniejsze od dotychczasowych oznaczeń materiałów z założenia młodszych. To właśnie takie rozumowanie skłoniło do wyboru z puli dat uzyskanych dla osady fazy sarnowskiej w Łącku (stan. 6A) - oznaczenia starszego od pozostałych dat dla KPL z Niżu i zarazem niemal identycznego z datą sarnowską (Domańska 1995, s. 10) ${ }^{4}$; skłaniało też do odrzucania oznaczeń, w których $\mathrm{w}$ odniesieniu do materiałów wczesnopucharowych uzyskano daty znacznie późniejsze od oczekiwanych, wkraczające już w zakres chronologiczny faz uznawanych za młodsze ${ }^{5}$. Podobnie odrzucano daty starsze, jako że KPL musi być młodsza od początków neolitu.

\footnotetext{
${ }^{3} \mathrm{Na}$ tej samej stronie K. Jażdżewski uznaje znaleziska $\mathrm{z}$ fazy sarnowskiej w Sarnowie za odpowiadające „mniej więcej” fazie „A” Beckera.

${ }^{4} \mathrm{Z}$ węgli drzewnych z czterech ,dołków posłupowych” uzyskano oznaczenia: 7220 $\pm 100 \mathrm{BP}$, $6870 \pm 110 \mathrm{BP}, 5970 \pm 120 \mathrm{BP}$ oraz 5570 $110 \mathrm{BP}$ (zbieżne z datą sarnowską). Dziegieć z łyżki glinianej ma oznaczenie: $5010 \pm 70$ BP. Połączono je z okresem budowy grobowca.

${ }^{5} \mathrm{Za}$ niemożliwą dla fazy sarnowskiej uznano najmłodszą datę z Łącka (por. poprzedni przypis). Odrzucono też z pola rozważań dwie daty uzyskane z prób kości ludzkich ze stanowiska 95 w Inowro-
} 
(2) Istnieją przesłanki, wobec których jednostkowa data z Sarnowa mogła być uznawana za możliwą dla początkowego etapu rozwoju KPL. Chodzi szczególnie o wskazywane związki wczesnej KPL z ugrupowaniami lendzielsko-polgarskimi (m.in. Wiślański 1973, 1979), zwłaszcza w odniesieniu do terenów Polski południowo-wschodniej (m.in. L. Czerniak 1989; 1994; Kukawka, 1991). Dostrzeganie tego rodzaju koneksji nie warunkuje bynajmniej traktowania daty sarnowskiej jako jednoznacznie poprawnej ${ }^{6}$. Odmiennie rzecz się ma z poszukiwaniem źródeł początków KPL (także idei megalityzmu w jej obrębie) na dalekim zachodzie, w Basenie Paryskim. Zdaje się, że dla akceptacji tego kierunku oddziaływań data sarnowska musi być poprawna (Rzepecki 2004, 2011).

(3) Istotnym utrudnieniem ewentualnego odrzucenia (bądź akceptacji) daty sarnowskiej był charakter i stan rozpoznania stanowisk z „najstarszymi” materiałami KPL. Niewielkie koncentracje zabytków i piaskowe podłoże mają swoje konsekwencje. Wielkość struktur podomowych (niekiedy tożsama z wielkością stanowiska) ogranicza możliwość typowania stanowisk do badań wykopaliskowych. Stanowiska piaskowe w przekonaniu wielu badaczy mają relatywnie niskie walory poznawcze i nie zachęcają do podejmowania prac wykopaliskowych ${ }^{7}$. Ich ograniczoność poznawcza ma również ten skutek, że trudno tam o odpowiednie jakościowo próby substancji organicznych przydatnych do wiarygodnych datowań radiowęglowych $^{8}$. Stąd zrodziło się prawomocne przekonanie, że z czasem kilkusetletnia luka, wskazywana już przez T. Wiślańskiego, pomiędzy datowaniem sarnowskim i kolejnymi może zostać wypełniona?

Dobrym argumentem wspierającym tego typu myślenie był fakt, że po ponad 30 latach od publikacji daty sarnowskiej wczesnym fazom KPL (fazy I-IIIA wg Kośko 1981) na Kujawach przypisano zaledwie 10 dat radiowęglowych (Rzepecki 2004, tab. 18) i tyle samo odnośnie do ziemi chełmińskiej (Kukawka 1997; Kukawka, Małecka-Kukawka, Wawrzykowska 2002, tab. 1) ${ }^{10}$.

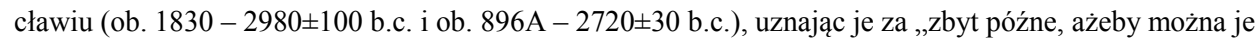
było uznać za powiązane z początkiem II fazy KPL” (Czerniak, Kośko 1993, s. 92).

${ }^{6}$ Sugerują one jedynie, że początki KPL winniśmy postrzegać w czasie trwania zjawisk postlinearnych, zwłaszcza tzw. kręgu lendzielsko-polgarskiego.

${ }^{7}$ Dobrym tego przykładem jest brak istotnych postępów w rozpoznaniu neolitu Mazowsza czy tzw. paraniżowych terenów Polski południowo-wschodniej, czego nie da się wytłumaczyć brakiem odpowiedniego lokalnego ludzkiego zaplecza badawczego.

${ }^{8}$ Rozrzut dat z Łącka 6A jest tu aż nadto wymowny.

${ }^{9}$ Respektowanie przywołanych przesłanek 1-3 spowodowało, że odrzucenie oznaczenia dotyczącego Sarnowa przez M. Nowaka (2009) nie zostało zaakceptowane przez S. Rzepeckiego (2011). Także autor tego tekstu, podzielając wątpliwości M. Nowaka, ostatecznie nie przychylił się do jego koncepcji (Kukawka 2010, s. 100).

${ }^{10}$ Pula dat odnoszących się do materiałów typu sarnowskiego/fazy sarnowskiej (KPL-s1 wg: Rzepecki 2004) wzbogaciła się zaledwie o wyniki analiz z dwóch stanowisk kujawskich: kontrowersyjna data z Łącka 6A i trzy interesujące oznaczenia stanowiska Strzelce-Krzyżanna 56. 
W ostatnich latach wiedza o początkach KPL na Niżu Polskim znacznie się poprawiła. Jest to efekt większego zainteresowania badaczy neolitu taką problematyką. Uzyskaliśmy wiele informacji dotyczących nowych stanowisk ${ }^{11}$. Znacząco wzrosła też pula dat radiowęglowych. $Z$ perspektywy poruszanej problematyki szczególne znaczenie mają stanowiska $z$ materiałami typu sarnowskiego $i$ analizy radiowęglowe $\mathrm{Z}$ nimi związane. $\mathrm{Z}$ jednej strony zmianie musi ulec postrzeganie zasięgu występowania omawianego typu materiałów. $Z$ drugiej zaś zdaje się, że rozumienie ich chronologii wymaga dokładnych korekt.

Zasięg stanowisk z materiałami typu sarnowskiego znacznie wykracza poza strefę Kujaw (Wielkopolska? Pomorze Zachodnie, Pomorze Nadwiślańskie).

$\mathrm{W}$ tym momencie istotniejsze są dane dotyczące chronologii bezwzględnej. Lista stanowisk datowanych jest następująca:

1. Sarnowo 1

a) $5570 \pm 60 \mathrm{BP}(\mathrm{GrN}-5033)$ - węgle drzewne z jamy 1 spod grobowca 8 (Bakker, Vogel, Wiślański 1969; Gabałówna 1970)

b) $4790 \pm 80 \mathrm{BP}(\mathrm{Ki}-15743)$ - fragment ceramiki z dołka 14 spod grobowca 8 (Rybicka 2011)

2. Sarnowo $1 \mathrm{~A}$

a) $4940 \pm 90 \mathrm{BP}$ (Ki-15742) - fragment ceramiki z warstwy III (Rybicka 2011)

3. Łącko $6 \mathrm{~A}$

a) $5570 \pm 110 \mathrm{BP}$ (Gd-6019) - węgle drzewne $\mathrm{z}$,dołka posłupowego" pod nasypem grobowca, trzy inne dołki otrzymały daty $7220 \pm 100,6870 \pm 110$ i $5970 \pm 120$ BP (Domańska 1995; Rzepecki 2004)

b) $5010 \pm 70$ BP (GifA-95488) - dziegieć z łyżki glinianej odkrytej pod poziomem nasypu (Domańska 1995; Rzepecki 2004)

4. Strzelce-Krzyżanna 56

a) $5020 \pm 60 \mathrm{BP}$ (Ki-6179) - kości zwierzęce z obiektu A6 (Rzepecki 2004)

b) $4980 \pm 50$ BP (Utc-8559) - kości zwierzęce z obiektu A6 (Rzepecki 2004)

c) $4950 \pm 50$ BP (Ki-6180) - kości zwierzęce z obiektu A6 (Rzepecki 2004)

5. Renice 5-6

a) $4975 \pm 35$ BP (Poz-34215) - dziegieć z jamy A39 na stanowisku Renice 5 (Rzepecki 2011)

b) $4995 \pm 35$ BP (Poz-31782) - kości z obiektu A31 na stanowisku Renice 6 (Rzepecki 2011)

c) $4990 \pm 35$ BP (Poz-31781) - kości z obiektu A22 na stanowisku Renice 6 (Rzepecki 2011)

6. Redecz Krukowy 20

a) $5150 \pm 40 \mathrm{BP}$ (Poz-24578) - substancja organiczna na ceramice (Papiernik 2012)

\footnotetext{
${ }^{11}$ Podjęto badania wykopaliskowe na wielu stanowiskach piaskowych uznawanych za „mało atrakcyjne" poznawczo. Nie bez znaczenia były tu tzw. badania ratownicze związane z inwestycjami budowlanymi.
} 
b) $5020 \pm 40 \mathrm{BP}(\mathrm{Poz}-24579)-\mathrm{j} . \mathrm{w}$.

c) $5010 \pm 40 \mathrm{BP}(\mathrm{Poz}-44442)-\mathrm{j} . \mathrm{w}$.

d) $5000 \pm 40 \mathrm{BP}(\mathrm{Poz}-30784)-\mathrm{j} . \mathrm{w}$.

e) $4980 \pm 40 \mathrm{BP}(\mathrm{Poz}-44441)-\mathrm{j} . \mathrm{w}$.

f) $4980 \pm 45 \mathrm{BP}(\mathrm{Poz}-44445)-\mathrm{j} . \mathrm{w}$.

g) $4960 \pm 40 \mathrm{BP}(\mathrm{Poz}-30787)-\mathrm{j} . \mathrm{w}$.

h) $4950 \pm 35 \mathrm{BP}(\mathrm{Poz}-44444)-\mathrm{j} . \mathrm{w}$.

i) $4900 \pm 35 \mathrm{BP}(\mathrm{Poz}-30788)-\mathrm{j} . \mathrm{w}$.

j) $4890 \pm 40 \mathrm{BP}(\mathrm{Poz}-30785)-\mathrm{j} . \mathrm{w}$.

k) $4780 \pm 110 \mathrm{BP}(\mathrm{Poz}-44446)-\mathrm{j} . \mathrm{w}$.

1) $4770 \pm 40 \mathrm{BP}(\mathrm{Poz}-30786)-\mathrm{j} . \mathrm{w}$.

m) $4740 \pm 40 \mathrm{BP}(\mathrm{Poz}-30782)-\mathrm{j} . \mathrm{w}$.

n) $4655 \pm 35 \mathrm{BP}(\mathrm{Poz}-30783)-\mathrm{j} . \mathrm{w}$.

o) $4580 \pm 60 \mathrm{BP}\left(\right.$ Lod-1584) - węgle drzewne (Papiernik 2012) ${ }^{12}$.

7. Inowrocław 95

a) 4930 \pm 100 BP (Gd-1985) - kości ludzkie z obiektu 1830 (L. Czerniak 1994; L. Czerniak, Kośko 1993)

b) $4670 \pm 30( \pm 110$ ?) BP (GrN-14021) - kości ludzkie z obiektu 896A (L. Czerniak 1994; L. Czerniak, Kośko 1993) ${ }^{13}$.

Datę z Łącka 6A (najmłodszą) oraz daty z Inowrocławia 95 (przynajmniej tę starszą) podaję tu nie bez powodu. W kontekście pozostałych nie ma istotnych podstaw do ich odrzucenia - w sensie datowania fazy sarnowskiej (Łącko) czy początków fazy II (Inowrocław).

Pula opublikowanych oznaczeń radiowęglowych dla materiałów tzw. fazy sarnowskiej (fazy I wg: Kośko 1981, KPLs1 wg: Rzepecki 2004) jest wystarczająca, by potwierdzić opinie M. Nowaka (2009) i M. Rybickiej (2011). Datę z Łącka można odrzucić z powodu jej spekulacyjnego wyboru (Nowak 2009; Rybicka 2011) oraz ze względu na fakt, iż oznaczenie najmłodsze (z dziegciu) znakomicie mieści się $\mathrm{w}$ przedziale wyznaczonym przez daty $\mathrm{z}$ innych stanowisk ${ }^{14}$. Osamotnioną datę

\footnotetext{
${ }^{12}$ Ze względu na to, że na tym wyjątkowo bogatym w zabytki stanowisku niewielką grupę ceramiki można łączyć z fazą wiórecką (hipotetyczny grobowiec bezkomorowy), trudno przed pełnym opracowaniem wyników badań określić górną datę dla materiałów typu sarnowskiego (Papiernik, 2012).

${ }^{13}$ W opracowaniu Czerniaka i Kośki (1993) ostrożnie zasugerowano możliwość łączenia obiektu z KAK, w pracy zaś Czerniaka (1994) data jest już jednoznacznie powiązana z KAK. W obu opracowaniach podano inne błędy standardowe dat.

${ }^{14}$ Obserwuje się częste lokowania grobów (w tym grobowców bezkomorowych) w miejscach wcześniejszych osad KPL. Jeśli uznamy, że nie jest to przypadek, lecz efekt działań świadomych, to trudno sobie wyobrazić, aby okres od opuszczenia osady do założenia grobowca wynosił ok. pół tysiąclecia. Stąd data dla dziegciu jest bardziej wiarygodna, bez względu na to, do którego faktu się odnosi. Jeśli, jak sugerują L. Domańska (1995) i S. Rzepecki (2004), odnosić ją do fazy budowy grobowca, to wówczas osada powinna być nieznacznie starsza.
} 
z Sarnowa 1 należy odrzucić z powodu trudnej do wytłumaczenia luki czasowej pomiędzy nią a innymi datami KPL (Nowak 2009), szczególnie pozostałymi datami odnoszącymi się do materiałów typu sarnowskiego. Za jej odrzuceniem przemawia też wiek fragmentu ceramiki spod grobowca 8 (Rybicka 2011). Odrzucenie tego datowania jest dzisiaj zdecydowanie bardziej uzasadnione niż wcześniejsze odrzucanie najmłodszej daty z Łącka 6A czy dat z Inowrocławia 95. Wątpliwości dotyczące tych oznaczeń wieku wynikały z niezachwianego przekonania, iż materiały typu sarnowskiego muszą być bezwzględnie starsze od wszelkich innych wiązanych z KPL, i co za tym idzie: z przeświadczenia o poprawności daty z Sarnowa. Obecna pula dat jednoznacznie wskazuje, że takie opinie były błędne, a data z Sarnowa 1 po niemal półwieczu poszukiwań nadal pozostaje niewiarygodnie osamotniona.

Przynajmniej tymczasowo dolną granicę fazy sarnowskiej (stylistyki sarnowskiej, materiałów typu sarnowskiego) wyznacza najstarsze datowanie z Redecza Krukowego 20, sugerujące w przybliżeniu lata 4000/3900 BC, co odpowiada początkom KPL na Niżu Polskim wg M. Nowaka (2009, s. 281-282, 347), szacowanym na około 4000 lat BC. Przyjmując nieco wcześniejsze datowanie początków KPL (np. dla ziemi chełmińskiej i okolic [Kukawka 2010]) na około 4200/4100 lat BC, można by nawet sugerować, że na polskich obszarach niżowych materiały typu sarnowskiego wcale nie są najstarsze ${ }^{15}$. Jeszcze trudniej wyznaczyć górną granicę chronologiczną omawianego zjawiska. Niejasny jest bowiem kontekst najmłodszych dat z Redecza Krukowego 20. Kolejnym stanowiskiem z najmłodszą datą jest Sarnowo 1 (spod grobowca 8). Sugeruje ona usytuowanie górnej granicy ok. 3600 lat BC.

Takie ramy chronologiczne wskazują na mozaikowość stylistyczną ceramiki już od początków trwania KPL na Niżu Polskim. Mieszczą się w nich bowiem bardzo zróżnicowane materiały uznawane za wczesne (kujawskich faz I-IIIA) ${ }^{16}$. Niestety specyfika dat radiowęglowych nie pozwala określić rzeczywistych relacji chronologicznych poszczególnych stylistyk ceramicznych. Chodzi tu zwłaszcza o niemożność rozstrzygnięcia hipotetycznej kolejności ich pojawiania się ${ }^{17}$. Okazuje się, że dotychczasowe metody typologiczno-chronologiczne całkowicie się nie sprawdziły. Nie można wszak wykluczyć, że przynajmniej na części obszarów niżowych materiały typu Podgaj-Przybranówek-Boguszewo były starsze od sarnowskich lub sar-

${ }^{15}$ Być może ma to związek ze zbyt małą liczbą datowanych stanowisk.

${ }^{16}$ Fazy I (sarnowskiej) i IIA (Czerniak, Kośko 1993), materiały typu Podgaj-PrzybranówekBoguszewo (Czerniak, Kośko 1993; Kukawka 1997), stylistyka wiórecko-jezuicka (Prinke 1988; materiały typu Toruń Mokre - Kukawka 1997), stylistyka wiórecko-łojewska (Szmyt 1992), materiały typu Sąsieczno 2 (Kukawka 2010) i inne (np. mieszane „bezzygzakowe” i „,wczesnozygzakowe” - wg: Kukawka 2010).

${ }^{17}$ Szczególnie istotne znaczenie miałoby tu określenie kolejności pojawiania się w różnych regionach Niżu materiałów typu sarnowskiego bądź podobnych (łączonych dotychczas z kujawskimi fazami I i IIA) oraz typu Podgaj-Przybranówek-Boguszewo (łączonych z kujawską fazą IIB). 
nowskich wcale nie było (choć w świetle bieżących określeń dat KPL była tam równie wczesna lub nawet starsza) ${ }^{18}$.

Przyjęcie „krótkiej” chronologii KPL niesie ze sobą istotne skutki interpretacyjne. Przede wszystkim ceramicznie wydzielana KPL już od samych początków jest na Niżu Polskim zróżnicowana. W obecnym stanie rozpoznania można wydzielić dwa odrębne nurty stylistyczne: materiały typu Sarnowo-Łącko-Strzelce-Krzyżanna oraz materiały typu Podgaj-Przybranówek-Boguszewo. Rozdrobnione materiały z osadowisk są rozróżniane na podstawie:

a) występowania talerzy i braku flasz z kryzą w typie pierwszym,

b) występowania flasz i braku talerzy w typie drugim,

c) występowania zdobień ryto-odciskanych, wiązanych z kulturami jordanowsko-śląską i schussenridzką w typie drugim,

d) bez wątpienia oba typy różnią się morfologicznymi detalami innych naczyń, zwłaszcza pucharów lejkowatych.

Zapewne da się wydzielić również inne rodzaje materiałów, np. zbliżone do typu drugiego, ale bez elementów jordanowsko-schussenridzkich, bądź zbiory ceramiki wykazujące cechy mieszane ${ }^{19}$. Bardzo nierównomierny stan rozpoznania najstarszej KPL w poszczególnych regionach ${ }^{20}$ i brak publikacji opracowań licznych w ostatnich latach badań ratowniczych oraz ciągle zbyt mała pula datowań radiowęglowych nie pozwalają określić, czy te oba style ceramiczne w swych początkach były osadzone terytorialnie. Tymczasowo można przedstawić ostrożną sugestię, że z perspektywy rozpoznania wczesnych materiałów KPL na Niżu Polskim zabytki typu sarnowskiego $^{21}$ są bardziej północno-zachodnie (Pomorze Zachodnie, Pomorze Gdańskie, obrzeża Kujaw, może też część Wielkopolski) ${ }^{22}$. Z kolei materiały typu boguszewskiego ${ }^{23}$ odkrywane są w strefie wschodniej (ziemia chełmińska, Kujawy, Wielkopolska) ${ }^{24}$.

${ }^{18} \mathrm{~Np}$. na ziemi chełmińskiej i w jej okolicach, gdzie do tej pory materiałów typu sarnowskiego nie zarejestrowano, przy relatywnie bardzo dobrym rozpoznaniu stanowisk wczesnych KPL (Kukawka 2010 oraz materiały ze stanowisk niepublikowanych).

${ }^{19}$ Nie wymieniłem znacząco odmiennych technologicznie i stylistycznie materiałów wiązanych z KPL z Pomorza (grupy łupawskiej czy stanowisk w Tanowie i Dąbkach; Galiński 2012; Jankowska 1980; Kabaciński, Terberger 2009; Wierzbicki 1999). Ich wczesna chronologia (w przedziale 41003900 lat BC), choć jest prawdopodobna, to jednak słabo poparta datowaniami radiowęglowymi.

${ }^{20}$ Relatywnie najlepszy na ziemi chełmińskiej i na Kujawach.

${ }^{21}$ Sarnowo-Łącko-Redecz Krukowy.

${ }^{22}$ Choć większość stanowisk rozpoznano na Kujawach, to może być to wynik bieżącego stanu badań terenowych. Warto bowiem zauważyć, że pozostałe stanowiska usytuowane są w regionach, które nie podlegały programowym badaniom wczesnych faz KPL (Kosin - badania przedwojenne, Renice na Pomorzu Zachodnim i Ropuchy na Pomorzu Gdańskim - badania ratownicze).

${ }^{23}$ Podgaj-Przybranówek-Boguszewo.

${ }^{24}$ Zastanawiający jest brak materiałów typu sarnowskiego $\mathrm{z}$ relatywnie najlepiej rozpoznanych terenów ziemi chełmińskiej (z okolicami) i przyległej do niej części Kujaw północno-wschodnich (w Kotlinie Toruńskiej i na terenach do niej przyległych). 
Pojedyncze stanowiska występują także w lewobrzeżnej części Doliny Dolnej Wisły ${ }^{25}$ czy na Pojezierzu Gostynińskim ${ }^{26}$. Pojedyncze elementy takiej stylistyki obecne są także w strefie starowysoczyznowej w Małopolsce ${ }^{27}$. Warto zauważyć, że w materiałach typu boguszewskiego pewną grupę zdobień wiąże się z wpływami południowo-zachodnimi (L. Czerniak, Kośko 1993). Być może zatem już od początków KPL na Niżu Polskim mamy do czynienia z kilkoma kierunkami oddziaływań kulturotwórczych: litoralnym $^{28}$, kontynentalnym północno-zachodnim ${ }^{29}$ i południowo-zachodnim ${ }^{30}$. Być może rysuje się interesujący, aczkolwiek bardzo złożony kierunek oddziaływań kulturotwórczych u początków KPL na Niżu Polskim ${ }^{31}$.

Ciągle zbyt mała pula dat radiowęglowych, jak również ich probabilistyczny charakter nie pozwalają na rozstrzygnięcie dwóch zasadniczych kwestii. Po pierwsze nie jesteśmy w stanie określić, która z przywoływanych stylistyk (typów) ceramiki $^{32}$ jest starsza - czy raczej wszystkie są równoczasowe ${ }^{33}$. Po wtóre i zarazem w związku z poprzednią uwagą nie można wskazać, czy początki KPL na Niżu Polskim mają charakter regionalny ${ }^{34}$ czy makroprzestrzenny. Jeśli prawdziwy byłby wariant pierwszy, to nie sposób wskazać obszaru inicjacyjnego. Stan rozpoznania terenowego nie wyklucza żadnego terenu, również pozaniżowego ${ }^{35}$.

Odrzucenie daty sarnowskiej musi skutkować przyjęciem jeszcze jednego wniosku, a mianowicie oddalającego pewne interpretacje genetyczne pojawienia się KPL na Niżu Polskim. Chodzi o poglądy łączące początki KPL z KCWR (L. Czerniak, Kośko 1993; Kośko 1981) z jednym z dwu nurtów rozwoju kujawskiej KPCW (L. Czerniak 1994) ${ }^{36}$ albo też poglądy o akulturacji eneolityzacyjnej, inspirowanej oddziaływaniami z obszaru Basenu Paryskiego (Rzepecki 2004). Zdaje się, że przywoływane $w$ tych koncepcjach ugrupowania kulturowe, mogące być inspiratorem bądź udziałowcem początków KPL, są zbyt wczesne wobec wymowy chronologii radiowęglowej początków KPL.

Wyjaśnienia wymaga jeszcze jedno przeświadczenie, że wczesna KPL jednoznacznie łączy się $\mathrm{z}$ terenami piaszczystymi ( $\mathrm{z}$ rolnictwem bielicoziemnym;

${ }^{25}$ Stare Marzy 4 (Kukawka 2012).

${ }^{26} \mathrm{~Np}$. Witoldów 1 i Helenów 1 (Rybicka 2004).

${ }^{27}$ Np. Gnojno 4 i Kawczyce 1 (Nowak 1996, 2009).

${ }^{28}$ Zjawiska obserwowane w grupie łupawskiej, Tanowie i Dąbkach.

${ }^{29}$ Powiązanym np. z kulturą michelsberską.

${ }^{30}$ Powiązanym np. z kulturami baalberską, jordanowsko-śląską i schussenridzką.

${ }^{31}$ Ogólnie zgodny z poglądami S. Rzepeckiego (2004), choć w innej, znacznie odmłodzonej chronologii.

${ }^{32}$ Litoralna, sarnowska, boguszewska.

${ }^{33}$ Obecnie można by (zapewne błędnie) sugerować, że najstarsze stanowiska KPL na Niżu Polskim znajdują się na ziemi chełmińskiej i na południe od niej (w Kotlinie Toruńskiej) (Kukawka 2010).

${ }^{34}$ Tak jak przy uznawaniu daty sarnowskiej można było traktować Kujawy.

${ }^{35}$ Także np. Małopolski.

${ }^{36}$ Efektem drugiego nurtu miałaby być tzw. grupa brzesko-kujawska. 
L. Czerniak 1994). Wśród badaczy Kujaw panuje przekonanie, że opanowanie przez ludność KPL obszarów gleb ciężkich (czarnoziemnych) było wtórne po długim okresie osadnictwa bielicoziemnego. Miałoby ono charakter stopniowej sukcesji po zanikającej KPCW (grupy brzesko-kujawskiej). Najwcześniejszy horyzont takiej sukcesji winny reprezentować materiały typu Łojewo (stylistyka wiórecko-łojewska), odnoszone do etapu związków z grupą małopolską KPL (Szmyt 1992). Zdaje się jednak, że pogląd taki jest wyłącznie efektem stanu badań, tzn. braku zainteresowania czołowych badaczy neolitu Kujaw początkami KPL na glebach ciężkich ${ }^{37}$. Przyjmując odmłodzoną chronologię początków KPL, należy zweryfikować pogląd o wyłączności zasiedlania gleb piaszczystych w tym czasie. Na podstawie wymowy danych archeometrycznych ten swoisty mit należy odrzucić. Otóż KPL nie jest od zarania zjawiskiem związanym ze środowiskiem piaskowym, w którym z czasem pojawiły się tendencje osadzania się na glebach ciężkich. Nasze myślenie należy zasadniczo odwrócić i przyjąć jedną z dwóch alternatywnych możliwości. W myśl pierwszej najwcześniejsza KPL na Niżu Polskim jest różnośrodowiskowa. Można też przyjąć, że jej początki wiążą się z glebami ciężkimi, piaskowość zaś wielu wczesnych stanowisk jest zjawiskiem wtórnym (młodszym). Obecnie nie można rozstrzygnąć tego dylematu. Istotne jest jednak to, iż od najwcześniejszych etapów swego rozwoju KPL obejmuje obszary o zróżnicowanym podłożu glebowym. Znakomitym przykładem bardzo wczesnego okupowania gleb ciężkich, tradycyjnie związanych $\mathrm{z}$ osadnictwem naddunajskim, jest stanowisko 43b w Boguszewie. Przedstawię skrótową wersję jego omówienia.

Nie wnikając głębiej w zawiłości badań powierzchniowych i realia badań wykopaliskowych, należy wskazać, że stanowiska 43a, 43b i 44 w Boguszewie stanowią jedną strukturę archeologiczną (jedno stanowisko). Niżej położona jej część (Boguszewo 43a) zawiera ślady osadnictwa najstarszej fazy KCWR na ziemi chełmińskiej (Kirkowski 1994). Partie wyżej położone to ślady osadnictwa (obiekty) KCWR i KPCW (Boguszewo 43b i 44) oraz KPL (Boguszewo 43b). Z perspektywy zasadniczego tematu tego tekstu istotny jest epizod osadnictwa KPL. Na rozległym stanowisku jego ślady obejmują powierzchnię nieprzekraczającą jednego ara (Kirkowski, Kukawka 1990; Kukawka 1991, 1997, 2010). Jednocześnie ceramika KPL to materiały typu Podgaj-Przybranówek-Boguszewo - i to z bardzo wczesnymi datami radiowęglowymi (Kukawka 2010). Zaobserwowana na tym stanowisku sekwencja chronologiczna znalezisk wskazuje, że materiały KPL występują bezpośrednio po osadnictwie KPCW (grupy brzesko-kujawskiej) ${ }^{38}$.

${ }^{37}$ Wydaje się, że badacze Kujaw badali czarnoziemne stanowiska KPL raczej przypadkowo, przy okazji prac podejmowanych z pobudek innych niż poznawanie materiałów tej kultury. Tego typu spostrzeżenie jest istotne z perspektywy wszelkich rozważań o początkach KPL na Niżu Polskim.

${ }^{38}$ Ceramika w stropowych partiach nie do końca jeszcze wypełnionych obiektów KPCW oraz w stropie glinianki KCWR, gdzie sekwencja stratygraficzna zabytków była następująca: KCWR-starsze KPCW-młodsze KPCW (grupa brzesko-kujawska)-KPL. 
Analiza wyników badań kompleksu stanowisk w Boguszewie pozwala na prezentację jeszcze kilku istotnych dla poruszanej problematyki wniosków. Przeprowadzone obserwacje stanowią interesujący przyczynek do dyskusji nad okresem schyłku KPCW (grupy brzesko-kujawskiej). Ponadto bardzo wyraźnie czytelne tu są różnice $\mathrm{w}$ charakterze zasiedlenia. Obszary z pozostałościami osadniczymi KCWR i KPCW każdorazowo są wielokrotnie większe od zasięgu ceramiki KPL. Interesujący jest też brak obiektów wziemnych KPL, przy relatywnie licznych obiektach z okresów wcześniejszych. Zaobserwowano typową dla stanowisk KPCW długą chronologię zasiedlenia, czytelną $\mathrm{w}$ charakterystyce ceramiki i w datach radiowęglowych (Kirkowski, Kukawka 1990; Kirkowski, Sosnowski 1994). Z kolei zaleganie i charakterystyka ceramiki KPL sugerować mogą jednorazowy pobyt $\mathrm{w}$ tym miejscu, a liczba fragmentów ceramiki wyklucza obozowiskowy charakter zasiedlenia. Warto zauważyć, że takie pozostałości po zasiedleniu wczesnopucharowym są typowe dla Niżu Polskiego, bez względu na podłoże glebowe ${ }^{39}$.

Ceramikę KPL o cechach wczesnych odkryto na wielu chełmińskich stanowiskach zlokalizowanych na glebach ciężkich, niekiedy w miejscach wcześniejszego zasiedlenia przez ugrupowania kręgu naddunajskiego ${ }^{40}$. Stanowisko w Boguszewie przywołane zostało ze względu na jasną strukturę stratygraficzną, znaczący liczebnie zbiór ceramiki KPL i w związku z tym jednoznaczne przyporządkowanie stylistyczne oraz wymowę oznaczeń radiowęglowych (zarówno dotyczących KPL, jak i $\mathrm{KPCW}$ ).

Łączne występowanie zabytków KPL z mezolitycznymi w strefie Niżu Polskiego jest na tyle rzadkie, że traktować je należy raczej jako niehomogeniczne, zwłaszcza że w żadnym znanym mi przypadku KPL nie reprezentuje fazy najstarszej, a mezolit fazy schyłkowej. Wydaje się zatem, że przypisywanie wczesnej KPL cech zasiedlenia mezolitycznego wynikało (wynika) bardziej z poglądu o „odmezolitycznej” koncepcji genezy tej kultury niż z rzetelnej analizy archeologicznej.

Datując początki KPL na około 4200/4100 lat BC, należy zastanowić się nad sytuacją kulturową w niżowej części ziem polskich w tym czasie. Potencjalny lokalny substrat populacyjny i kulturowy reprezentuje zaledwie kilka archeologicznie wy-

\footnotetext{
${ }^{39}$ Mała koncentracja (małe koncentracje) zabytków i jednorodność stylistyczna ceramiki, sugerujące jednorazowy, krótkotrwały pobyt (kilka? kilkadziesiąt? lat) lub powtarzalność zasiedlenia w krótkich odstępach czasu. Charakterystyczny jest też niemal całkowity brak wyraźnych obiektów wziemnych.

${ }^{40}$ Stan rozpoznania na 1994 r.; por. Kukawka 1994, tab. 1. Obecnie listę tam zaprezentowaną należałoby rozszerzyć. Podobne następstwo KPCW-materiały KPL typu sarnowskiego zarejestrowano także np. na Pomorzu Zachodnim, na stanowisku 5-6 w Renicach (Rzepecki 2011, s. 26, 36). Nowego znaczenia w tym kontekście nabierają datowane radiowęglowo materiały KPL ze stanowiska $35 \mathrm{w}$ Łojewie, gdzie stwierdzono wcześniejsze ślady osadnictwa związane z KCWR. Można tu też przywołać wczesnopucharowe materiały ze stanowiska $95 \mathrm{w}$ Inowrocławiu i 7A w Podgaju, na których stwierdzono ślady wcześniejszego osadnictwa KPCW (Czerniak, Kośko 1993). Zasadniczo podobne sugestie odnośnie do stanowisk KPL w Wielkopolsce wyraża J. Wierzbicki (2013).
} 
różnianych zjawisk kulturowych. Ze społeczności wczesnorolniczych należy wymienić dwa ugrupowania związane $\mathrm{z}$ tzw. kręgiem naddunajskim: grupę (kulturę) brzesko-kujawską oraz kulturę (grupę) jordanowsko-śląską. Wśród społeczności zbieracko-łowieckich należy rozważyć dwa rozróżniane archeologicznie warianty: bezceramiczny (tradycyjnie mezolityczny) i ceramiczny (subneolityczny $=$ paraneolityczny).

Wydaje się, że okres rozprzestrzeniania się wczesnej KPL zbiega się z poważnym kryzysem i w rezultacie zanikiem grupy brzesko-kujawskiej, choć w poglądach istnieją spore rozbieżności. Według R. Grygiela jej zanik powinien nastąpić ok. 4000 lat BC (Grygiel 1986, 2008). Z kolei L. Czerniak (1994) widziałby go raczej ok. 3650 lat BC. Nie odrzuca on ewentualnej poprawności hipotezy R. Grygiela, ale słusznie wskazuje, że seria dat dotyczących Kujaw pochodzi z osad centralnych, a więc w proponowanym czasie to one mogły przestać funkcjonować na rzecz bardziej rozproszonych osiedli mniejszych. Można zatem przypuszczać, że owe mniejsze osiedla schyłkowe (KPCW IIIb-c wg Czerniak 1980) winny być relatywnie liczne, czego nie potwierdzają dotychczasowe badania. Wydaje się, że przeprowadzona w opracowaniu R. Grygiela (2008) analiza kalibracyjna 75 dat nakazuje przyjęcie końca KPCW na ok. 4000 lat BC (przynajmniej tymczasowo ${ }^{41}$. Dobrym przyczynkiem potwierdzającym taką opinię jest przedstawiona wcześniej sytuacja w Boguszewie 43b. Choć dotyczy ona historii zasiedlenia pojedynczego miejsca, to jednak ukazuje bardzo wczesną sukcesję zasiedlenia (po KPCW przez KPL). Być może jest to charakterystyczne wyłącznie dla enklawy chełmińskiej, niemniej skromne informacje z innych stanowisk (wspomniane wcześniej) sugerują, że pełny zanik archeologicznie identyfikowanej grupy brzesko-kujawskiej nie powinien być później-

\footnotetext{
${ }^{41}$ Obaj badacze są zwolennikami hipotezy łączącej genezę KAK z grupą brzesko-kujawską. Akceptują oni jednostkowe datowanie węgli drzewnych z obiektu w Kruszy Zamkowej 13 (L. Czerniak 1994, ryc. 2; Grygiel 2008, tab. CCXLVI), choć L. Czerniak zdaje się wykazywać w tej materii pewną ostrożność. Z tą jednostkową datą (5140 140 BP; Szmyt 1996) wiążą się problemy podobne do tych związanych z datą sarnowską. Rachunek prawdopodobieństwa jednoznacznie sugeruje jej odrzucenie. Przywoływana przez L. Czerniaka data zaniku grupy brzesko-kujawskiej jest bezwzględnie bardziej wiarygodna w odniesieniu do początków KAK (np. zestawienie dat radiowęglowych KAK - Szmyt 1996, tab. 17 i 18). Takie prawdopodobieństwo zdaje się ostrożnie przedstawiać L. Czerniak (1994, s. 85-86, 107). W problematykę początków KAK wpisują się też przyjmowane jej związki z KPL - i to już od wydzielanych amforowych materiałów potencjalnie najwcześniejszych. $Z$ takiej perspektywy początki KAK nie powinny wyprzedzać daty 3700/3600 lat BC, bo tak należałoby datować potencjalne wzorce zdobnictwa KPL zapożyczone przez KAK.

Wobec wymowy aktualnych danych typologicznych i datowań radiowęglowych coraz bardziej wątpliwe jest łączenie genezy KAK z grupą brzesko-kujawską (Kurzyk 2013). Sugerujący ciągłość kulturową (KPCW-KAK) argument technologiczny (L. Czerniak 1980, 1994; E. Czerniak, L. Czerniak 1985), sprowadzający się zasadniczo do podobieństw domieszek schudzających masę ceramiczną, nie jest tu wystarczający. Zbliżone warianty tej cechy spotkać można np. w ugrupowaniach KPL (w Polsce np. na Pomorzu), jak również w zjawiskach subneolitycznych.
} 
szy niż ok. 3900 lat BC. Wydaje się zatem, że przywoływana przez L. Czerniaka (1994) mozaika kulturowa, z równoległym rozwojem grupy brzesko-kujawskiej i KPL, ograniczona być musi z ok. 900/800 lat trwania do maksymalnie 200/100 lat.

Stan rozpoznania kultury (grupy) jordanowskiej (jordanowsko-śląskiej) znacząco utrudnia oszacowanie jej schyłku. Dysponujemy zaledwie dwiema przesłankami sugerującymi jej koniec dopiero w czasie trwania KPL. Pierwszą jest charakter jednej z najstarszych stylistyk ceramiki KPL, a mianowicie materiałów typu Podgaj-Przybranówek-Boguszewo, o ile poprawnie zidentyfikowano pewne zdobienia jako wpływy jordanowsko-schussenridzkie. Drugą przesłanką jest wyposażenie dwóch grobów z Jordanowa Śląskiego, w których znaleziono naczynia grupy jordanowsko-śląskiej i KPL (Wiślański 1979, ryc. 97:1-12). Jeśli wyposażenie tych grobów uznać za zespoły, to schyłek omawianego zjawiska być może należy widzieć ok. 3800/3700 lat BC ${ }^{42}$.

Podsumowanie stanu rozpoznania schyłkowego mezolitu na ziemiach polskich (w kontekście genezy KPL) przedstawił M. Nowak (2009). Z tego opracowania, jak również innych (np. Galiński 1997) wynika, że wiedza o bezceramicznych (mezolitycznych) grupach zbieracko-łowieckich okresu schyłkowoatlantyckiego jest wysoce hipotetyczna czy wręcz zdroworozsądkowa. Wynika to z dwu podstawowych przyczyn. Stan rozpoznania mezolitu daleki jest od zadowalającego. Przeszkodą jest też piaskowy charakter stanowisk, skutecznie utrudniający wykonywanie oznaczeń wieku metodą radiowęglową. Wyrażane niekiedy przekonanie (np. Nowak 2009) o dobrej kondycji kulturowej ${ }^{43}$ i biologicznej ${ }^{44}$ tego typu społeczności na terenach zajętych przez najstarszą KPL nie ma dostatecznych choćby podstaw źródłowych ${ }^{45}$. Przedneolityczne społeczności mezolityczne niżowych obszarów Polski zasiedlały tereny leśne o podłożu piaskowym. Wcześni rolnicy osiedlali się natomiast w strefach gleb ciężkich. To środowiskowe zróżnicowanie wyboru miejsc zamieszkania oraz przekonanie o skrajnie odmiennej diecie ${ }^{46}$ legły u podstaw powszechnej opinii o braku konkurencyjności eksploatacyjnej środowiska czy wręcz o kooperacji ${ }^{47}$. Licznych zwolenników ma ewolucjonistyczne założenie o cywilizacyjnej wyższości (postępowości) społeczności agrarnych nad zbieracko-łowieckimi - i w związku z tym atrakcyjności dla tych ostatnich gospodarki wytwórczej $^{48}$. Społeczności wiązane z archeologiczną KPL jako pierwsze ugrupowania wczesnoagrarne przełamały barierę ekologiczną ${ }^{49}$, zasiedlając

\footnotetext{
${ }^{42}$ Puchar lejkowaty z grobu 28 (Wiślański 1979, ryc. 97:4).

${ }^{43}$ Zdolność do relatywnie szybkiej adaptacji złożonych zachowań kulturowych, w tym m.in. także tych związanych z uprawą ziemi i chowem zwierząt, wytwarzaniem ceramiki, megalityzmem itp.

${ }^{44}$ Odpowiednio liczebna populacja.

${ }^{45}$ Bez względu na przyjmowany pogląd o chronologii początków KPL.

${ }^{46}$ Rośliny i zwierzęta dzikie versus udomowione.

${ }^{47}$ Por. wątpliwości dotyczące takiego ujęcia (Kukawka 1997).

48 Trwałość takiego poglądu jest w pewnym stopniu efektem akademickiej edukacji archeologów.

49 Jest to oczywiście pewne uproszczenie problemu.
} 
obszary poza wyspami osadnictwa „naddunajskiego”. Nie może być to jednak równoznaczne z procesem neolityzacji mezolitu, o którego istnieniu w tym czasie (ok. 4200/4100 lat BC) nie wiemy praktycznie $n \mathrm{c}^{50}$. Odmiennie rzecz wygląda z drugą wyróżnioną archeologicznie odmianą świata zbieracko-łowieckiego, którą będę określał mianem ,subneolit" ${ }^{\text {"51 }}$.

Choć rozpoznanie archeologiczne zjawisk wiązanych z subneolitem na ziemiach polskich jest znacznie lepsze od znajomości schyłkowego mezolitu, to jednak nadal odległe od zadowalającego. W omawianym przedziale czasowym zidentyfikowano je w dwóch regionach: w pomorskiej strefie litoralu Bałtyku oraz na obszarach Polski północno-wschodniej. Zastanawiać może fakt, że zbliżonych stanowisk nie zarejestrowano w przestrzeni wypełniającej enklawy (wyspy) wczesnoagrarnego osadnictwa naddunajskiego. Jest to szczególnie intrygujące w odniesieniu do stwierdzenia, że wspomniane enklawy mają długie, liczące ok. 1,5 tysiąclecia tradycje zasiedlenia, które miało dostatecznie intensywny i trwały charakter. Wydaje się mało prawdopodobne, by był to efekt niedostatecznego stanu badań ${ }^{52}$. Rysuje się zatem ciekawa perspektywa poznawcza. Można bowiem zastanowić się nad przyczyną rozprzestrzenienia się ceramicznych grup zbieracko-łowieckich poza zasięgiem osadnictwa naddunajskiego (na północ, północny wschód i wschód od niego) i ich całkowitego braku pomiędzy jego enklawami ${ }^{53}$. Oczywiście nie można wykluczyć koncepcji o przetrwaniu tam tradycyjnych społeczności mezolitycznych ${ }^{54}$, choć, jak już wspomniano, w praktyce nie ma ona podstaw źródłowych.

Wydaje się, że należy zrezygnować $\mathrm{z}$ przedstawianego w literaturze obrazu dwóch światów - zbieracko-łowieckiego i rolniczo-hodowlanego właśnie w kategoriach podstaw zdobywania pożywienia. W związku z tym należy stanowczo odrzucić pogląd o bezkonfliktowym czy choćby bezkonkurencyjnym wkroczeniu grup wczesnoagrarnych w świat mezolitycznych zbieraczy i łowców. Mniemanie takie wynikało z obserwacji, że te „dwa światy kulturowe” różnią środowiskowe uwarunkowania miejsc zamieszkania, a także z przekonania, iż dla społeczności naddunajskich zbieractwo i łowiectwo, choć rejestrowane i akceptowane, miało znaczenie marginalne. Nie wydaje się, by takie podejście było poprawne (por. Kukawka 1997, 2000). Nie to jest jednak najistotniejsze. Znacząco ważniejsza byłaby skala eksploatacji środowiska przez społeczności wczesnoagrarne ${ }^{55}$, zwłaszcza w aspekcie po-

\footnotetext{
${ }^{50}$ Przywoływane przez archeologów domniemane materialne dokumentacje wzajemnych relacji społeczności mezolitycznych i wczesnych neolitycznych nie są wystarczająco wiarygodne. Wymagają refleksji i weryfikacji. W żadnej mierze nie przekonują o neolityzacji mezolitu. Co najwyżej argumentują wzajemne relacje „obu światów”.

${ }^{51}$ O problemach nomenklaturowych por. Kukawka 2010.

${ }^{52}$ Choć ostatecznie nie można wykluczyć takiej ewentualności.

${ }^{53}$ Osobnym problemem są wyraźne różnice w charakterystyce naczyń ceramicznych.

${ }^{54}$ Taką koncepcję lansuje ostatnio M. Nowak (2009).

${ }^{55}$ Chodzi tu o sumaryczne znaczenie dla tradycyjnego, mezolitycznego stylu życia, a więc zapewne o lokalne odlesienia z powodu upraw i chowu, zdobywanie paszy, materiału budowlanego i opałowego,
} 
wszechnego przekonania o ich znacząco większej sile populacyjnej w stosunku do zbieraczy i łowców. Co najmniej równie uprawniony jest pogląd, że wczesnoagrarni migranci z południa eksploatowali środowisko w porównywalnym bądź większym stopniu niż zbieracze-łowcy. Jeśli taka koncepcja byłaby słuszna, to należałoby się liczyć ze znaczącym rozrzedzeniem bądź stopniowym zanikiem społeczności mezolitycznych pomiędzy enklawami osadnictwa wczesnorolniczego ${ }^{56}$.

Pomijając złożone przyczyny trudności jednoznacznego przyporządkowania kulturowego mocno zróżnicowanych zbiorów ceramiki subneolitycznej, należy wskazać na kilka zjawisk rozwijających się ok. początków KPL. W strefie litoralnej obserwujemy ceramikę bardziej bądź mniej nawiązującą do KE-E. Na szczególną uwagę zasługują tu materiały z kompleksu stanowisk w Tanowie (Galiński 1990, 1992, 2005) oraz ze stanowiska w Dąbkach (Ilkiewicz 1989; Kabaciński, Terberger 2009). Cytowani badacze zdają się sugerować, że zaobserwowali proces przemian ceramiki z KE-E ku KPL ${ }^{57}$.

Na terenach Polski północno-wschodniej w interesującym nas okresie mogłyby występować aż cztery wydzielane archeologicznie kultury ceramiczne: kultura niemeńsko-prypecka (= materiały typu Dubičaj kultury niemeńskiej) ${ }^{58}$, kultura (krąg kulturowy) Narva ${ }^{59}$, kultura ceramiki grzebykowej ${ }^{60}$ i kultura Zedmar (materiały typu Zedmar) ${ }^{61}$.

W kontekście rozważań dotyczących ludności subneolitycznej jako potencjalnego lokalnego substratu populacyjnego kształtującej się KPL interesujących obserwacji dostarcza ziemia chełmińska. Jednoznacznie jest tam czytelny proces „,subneolityzacji" ceramiki KPL. Jedyne stanowiska tej kultury bez ceramiki o cechach subneolitycznych łączą się wyłącznie z najstarszą fazą rozwojową ${ }^{62}$. W jej dalszym rozwoju lokalne społeczności subneolityczne miały znaczący udział kulturowy

ale nie tylko. Warto też zastanowić się nad skalą zbieracko-łowieckiej eksploatacji otoczenia naturalnego przez społeczności wczesnoagrarne (Kukawka 1997, 2000).

${ }^{56}$ Zmierzam tu do wyrażenia poglądu, że osadnictwo wczesnoagrarne nie może być postrzegane wyłącznie jako rolniczo-hodowlane - i w związku z tym obojętne wobec tradycyjnego: mezolitycznego. Oba ,światy” były głęboko konkurencyjne i zapewne wrogie.

${ }^{57}$ Choć raczej o cechach grupy północnej KPL.

${ }^{58}$ Poza zasięgiem wczesnej fazy KPL.

${ }^{59} \mathrm{Na}$ południowo-zachodniej rubieży, m.in. na ziemi chełmińskiej w zasięgu najstarszego etapu rozwoju KPL (Kukawka 2010).

${ }^{60}$ Raczej poza zasięgiem najstarszej KPL; w tym czasie zabytki nawiązujące do kręgu grzebykowego znamy z terenów Łotwy. Stan badań nad KCG (jak i wielu innych zjawisk z terenów Europy północno-wschodniej) i co za tym idzie - także chronologią i zasięgiem rozprzestrzenienia daleki jest od zadowalającego.

${ }^{61}$ Poza zasięgiem najstarszej KPL. Ponadto analiza dat radiowęglowych (zwłaszcza z Zedmara A i D) może sugerować, iż był to „epizod kulturowy”, i to nieco młodszy od początków KPL (Kukawka 2011; Kozicka 2012).

${ }^{62}$ Tu szczególnie wyrazistym przykładem są zabytki ze wspomnianego wcześniej Boguszewa 43b. 
i zapewne populacyjny (Kukawka 1997, 2010). Warto też wskazać na rozległość czytelnych ceramicznie oddziaływań wczesnej KPL w głąb świata subneolitycznego (Gaerte 1927; Gumiński 2011; Loze 1988; Wawrusiewicz 2011). W takim kontekście należy zaakcentować umowność przywołanego określenia „subneolityzacja KPL”. Równie poprawnie brzmiałby tu termin ,pucharyzacja subneolitu”. Można zatem postawić zasadne pytanie o charakter procesów, które kiedyś mogły zaistnieć na stanowiskach ze strefy litoralnej. Zabytki ceramiczne tam występujące $\mathrm{w}$ równym stopniu argumentują dwie alternatywne hipotezy: (1) kształtowania się KPL z KE-E w efekcie ewolucji (?) lub oddziaływań innych kultur albo (2) pucharyzacji KE-E w efekcie oddziaływań istniejącej już KPL ${ }^{63}$. Nieliczne stanowiska polskie należałoby rozpatrywać w łączności z tymi ze strefy, w której kształtuje się tzw. grupa północna KPL.

Wypowiadając się o genezie KPL, należy uznać wyróżniony archeologiczny byt badawczy za odpowiadający w jakimś sensie dawnej rzeczywistości ${ }^{64}$. Jesteśmy zatem przekonani, że „odtworzyliśmy”, choćby ułomnie, fragment dawnego, realnego zróżnicowania kulturowego. Jednak wydzielenie KPL (także jej grup terytorialnych czy nawet faz rozwojowych) opiera się na współczesnym wyodrębnieniu pewnego rodzaju ceramiki naczyniowej. Oznacza to, że uznaliśmy, iż obserwowane przez nas zróżnicowanie cech ceramiki odzwierciedla w jakimś zakresie realne pradziejowe zróżnicowanie kulturowe. Ceramika stanowi też podstawę przyporządkowania kulturowego badanych stanowisk ${ }^{65}$. Elementy ich struktury - konteksty występowania ceramiki $^{66}$ - określane są wtórnie. Choć badacze przywołują nieco elementów, które zdają się pozytywnie korelować $\mathrm{z}$ ceramiką ${ }^{67}$, to nie należy zapominać, że jest to tylko korelacja jednostronna ${ }^{68}$. Pewną pozytywną wartością jest to, że niezależne od procedur archeologicznych datowania radiowęglowe zdają się owe korelacje wspierać - lecz i one nie dają ostatecznych rozstrzygnięć. Wobec tak zarysowanej rzeczywistości archeologicznej (badawczej) przy rozważaniu problematyki genezy KPL ${ }^{69}$ w pierwszej kolejności trzeba zastanowić się nad analizowanymi cechami ceramiki.

${ }^{63}$ Ostatnia ewentualność byłaby w swej istocie podobna do sytuacji z ziemi chełmińskiej. Określenie efektu takiej pucharyzacji jako kolejnej fazy KE-E bądź jako nowej kultury - KPL - zależy wyłącznie od postawy badacza.

${ }^{64} \mathrm{~W}$ przeciwnym razie dociekanie genezy będzie banalnie proste i doprowadzi nas do archeologii początków XX w., kiedy to powołano KPL do życia.

${ }^{65}$ By się o tym przekonać, wystarczy sięgnąć do dowolnego opracowania wyników badań wykopaliskowych.

${ }^{66}$ Obiekty wziemne, tzw. warstwy kulturowe, groby, krzemienie i inne zabytki, lokalizacja i wielkość sadowisk czy cmentarzysk, przyporządkowanie szczątków osteologicznych itp.

${ }^{67}$ Zwłaszcza w ujęciach regionalnych.

${ }^{68}$ Dobrym przykładem może tu być korelacja wczesnych odmian ceramiki KPL w niektórych regionach ze zwiększoną frekwencją krzemieni czekoladowych. Wystarczy zadać pytanie, jak w tych regionach krzemień czekoladowy koreluje z ceramiką. Okaże się, że nie ze wszystkimi stanowiskami wczesnej KPL i nie tylko z KPL.

${ }^{69}$ Każdej kultury „odceramicznej”. 
Problem tkwi w tym, że owe cechy w swym całokształcie są odmienne od całego otaczającego świata ceramicznego, bo to one (a przynajmniej część z nich) stanowiły podstawę wydzielenia $\mathrm{KPL}^{70}$.

Należy zatem zauważyć, że ceramiki KPL na Niżu Polskim nie da się wprost powiązać genetycznie z lokalnymi ugrupowaniami kulturowymi. Zarazem zasiedlanie przez ludność nowo ukształtowanej jakości kulturowej już od samego początku środowisk bardzo zróżnicowanych, od tych ukształtowanych na glinach ciężkich po te uformowane na piaskach luźnych, świadczy o wyjątkowej i niespotykanej wcześniej elastyczności osadniczo-gospodarczej. $Z$ tej perspektywy można przypuszczać, że społeczności te posiadały długie, wielopokoleniowe tradycje w zakresie rolniczych sposobów pozyskiwania żywności z umiejętnością stosowania ich w dowolnych warunkach środowiskowych.

Stanowiska najstarszej KPL odkrywamy w rejonach wcześniejszego osadnictwa grupy brzesko-kujawskiej bądź w ich bezpośrednim sąsiedztwie. Istotne jest też to, że początki KPL zbiegają się z kryzysem i rozpadem grupy brzesko-kujawskiej, aż do jej archeologicznego zaniku. Kryzys ten ma znacznie szerszy wymiar przestrzenny i chronologicznie zbiega się z okresem istotnych zmian klimatu, które dla społeczności agrarnych zawsze niosły dramatyczne skutki. Proces rozpadu struktur postlinearnych $^{71}$, bez względu na przyczyny, musiał spowodować złożony łańcuch przypadkowych zdarzeń, które doprowadziły do ukonstytuowania się nowych sieci i uwarunkowań relacji międzygrupowych. Rekonstrukcja owych zdarzeń zapewne nie będzie możliwa. Można natomiast poszukiwać niektórych ich uczestników.

Wiele cech najstarszej ceramiki KPL na Niżu Polskim wskazuje na związki $\mathrm{z}$ ugrupowaniami postlinearnymi. Stosowanie tłucznia ceramicznego jako domieszki schudzającej masę ceramiczną nawiązuje do małopolskich ugrupowań lendzielsko-polgarskich oraz do kultury malickiej. Należy też zauważyć, że domieszka taka pojawia się w ceramice późnych faz grupy brzesko-kujawskiej ${ }^{72}$. Wiele cech zdobnictwa naczyń nawiązuje właśnie do kultur postlinearnych. Można tu wskazać na ubóstwo zdobień, typy odciskanych elementów zdobniczych czy dominację wątków podkrawędnych zewnętrznych. Na szczególną uwagę zasługują specyficzne zdobienia brzuścowe, charakteryzujące tzw. materiały typu Podgaj-Przybranówek-Boguszewo, a identyfikowane jako wpływy jordanowsko-schussenridzkie ${ }^{73}$. Niemal wszystkie formy naczyń wczesnej KPL, z pucharem lejkowatym włącznie, da się

${ }^{70}$ Także jednostek pochodnych: grup terytorialnych czy regionalnych, stylistyk, tzw. faz rozwojowych itp. Zapewne jest to podstawowa przyczyna każdorazowo raczej spekulacyjnego rozstrzygnięcia w problematyce genezy KPL, wielości poglądów i ich nikłej zmienności wobec ogromnego przyrostu informacji źródłowych.

${ }^{71} \mathrm{~W}$ typie grupy brzesko-kujawskiej, kultury malickiej, ugrupowań lendzielsko-polgarskich, kłuto-rösseńskich itp.

${ }^{72}$ Zapewne jako element oddziaływań południowych.

${ }^{73}$ Według: L. Czerniak, Kośko 1993. 
wyprowadzić z sąsiedzkich kultur postlinearnych, choć oczywiście lista potencjalnych „dawców” jest znacznie szersza ${ }^{74}$.

Analizując ceramikę wczesnej KPL na Niżu Polskim, można by przyjąć, że jest ona wersją (może nieco zubożoną) należącą do ugrupowań postlinearnych ${ }^{75}$. Nasze postrzeganie jej odrębności może być przesadzone i spowodowane uwarunkowaniami historycznymi. Wpływ na to ma wczesne wydzielenie KPL jako odrębnej archeologicznej jednostki kulturowej, a także zakorzenione od dawna (ale i bieżące) poglądy dotyczące genezy związanej z substratem populacyjnym zbieracko-łowieckim i lokujące ją w grupie kultur północnych, opozycyjnej w stosunku do południowych ugrupowań naddunajskich. Niemały wpływ na odrębne traktowanie miała data sarnowska i zakładany równoległy rozwój z grupą brzesko-kujawską i zasiedlaniu odrębnych względem niej nisz ekologicznych. Zauważano też istotne różnice właśnie w odniesieniu do grupy brzesko-kujawskiej (widoczne w ceramice, charakterystyce osadowisk, śladach po domostwach, grobach itp.).

Trudno oszacować udział lokalnej ludności grupy brzesko-kujawskiej w kształtowaniu się KPL. Z jednej strony czytelne jest zróżnicowanie technologiczne ceramiki obu kultur, z drugiej zaś domieszka „szamotowa” spotykana jest w naczyniach grupy brzesko-kujawskiej, tłucznia kamiennego zaś na niektórych wczesnych stanowiskach KPL. Zapewne poza społecznościami postlinearnymi w kształtowaniu KPL na Niżu Polskim brały udział również inne ugrupowania. $Z$ perspektywy analiz ceramicznych ich wskazanie nie będzie łatwe. Być może warto skierować uwagę na jakieś oddziaływania zachodnie, czytelne $\mathrm{w}$ zjawisku megalityzmu ${ }^{76} . \mathrm{Na}$ bardziej złożony przebieg zdarzeń zdaje się wskazywać zróżnicowanie ceramiki ze stanowisk najstarszych, łączonych do tej pory z kujawskimi fazami I, IIA i IIB.

Odrębnym problemem są kwestie rozpoznania tego wczesnego okresu i możliwości oszacowania synchroniczności tak zróżnicowanych materiałów od samych początków KPL. Dobrym przykładem dynamiki zdarzeń jest sytuacja zaobserwowana w północno-wschodniej części Niżu Polskiego ${ }^{77}$. Stwierdzono, że tuż po pojawieniu się KPL nastąpiło włączenie lokalnych grup subneolitycznych w nową sieć obiegu informacji (Kukawka 2010). Przesunięcie początków KPL do ok. 4200/4100 lat $\mathrm{BC}^{78}$ zaciera dotychczasowy obraz ${ }^{79}$. Z jednej strony charakter i niedostatek dat

${ }^{74}$ Wyjątek stanowią tzw. flasze z kryzą, które są formą oryginalną.

${ }^{75}$ Do ugrupowań tych jednoznacznie nawiązuje krzemieniarstwo wczesnej KPL (zob. np. Domańska 1995; Lech, Młynarczyk 1981; Małecka-Kukawka 1992). Marek Nowak (2009) lansując genetyczne związki KPL z mezolitem, z niezrozumiałych przyczyn całkowicie pominął tę kategorię zabytków.

${ }^{76} \mathrm{O}$ ile megalityzm w KPL na Niżu Polskim sięga początków trwania tej kultury, co nie jest pewne. Nie są też jasne jego związki genetyczne z zachodnią Europą (np. poglądy zwracające uwagę na zbieżność formalną tzw. grobowców kujawskich (i do nich podobnych) z domami grupy brzesko-kujawskiej).

${ }^{77}$ I zarazem północno-wschodniej rubieży ekumeny KPL.

${ }^{78}$ A może nawet do ok. 4000 BC (Nowak 2009).

${ }^{79} \mathrm{~Np}$. przyjmowanie daty sarnowskiej pozwalało na wskazywanie Kujaw jako terytorialnej prakolebki KPL, materiały typu sarnowskiego zaś - na uznawanie ich za najstarsze. 
radiowęglowych $^{80}, \mathrm{z}$ drugiej zróżnicowanie stylistyczne wczesnych materiałów ${ }^{81}$ powodują, że odpowiedzi na pytania o czasowo-przestrzenne początki KPL pozostają otwarte ${ }^{82}$.

\section{BIBLIOGRAFIA}

Bakker J.A., Vogel J.C., Wiślański T.

1969 TRB and other C14 Dates from Poland (ca. 4300-1350 BC and 800-900 AD). Helinium, 9, s. 3-27, 209-238.

Becker C.J.

1947 Mosefunde Lerkar fra yngre Stenalder. Aarbøger, 1947, 1-318, I-XVIII.

Czekaj-Zastawny A., Kabaciński J., Terberger T.

2011 Relacje łowiecko-zbierackich społeczności z Dąbek z kulturami neolitycznymi Europy Środkowej. W: U. Stankiewicz, A. Wawrusiewicz (red.), Na rubieży kultur. Badania nad okresem neolitu $i$ wczesna epoka brąu (s. 161-174). Białystok: Muzeum Podlaskie w Białymstoku.

Czerniak E., Czerniak L.

1985 Z badań nad genezą i rozwojem kultury amfor kulistych na Kujawach. Folia Praehistorica Posnaniensia, 1, s. 23-62.

Czerniak L.

1980 Rozwój społeczeństw kultury późnej ceramiki wstęgowej na Kujawach. Poznań: Uniwersytet im. Adama Mickiewicza.

Czerniak L.

1989 Teoretyczne problemy archeologicznej systematyki kulturowej. Przykład badań nad zróżnicowaniem cech technologicznych ceramiki kultur z kręgu naddunajskich. W:

A. Cofta-Broniewska (red.), Kujawskie przyczynki do badań nad neolitem Europy (s. 33-76). Inowrocław: Uniwersytet im. Adama Mickiewicza w Poznaniu.

Czerniak L.

1994 Wczesny i środkowy okres neolitu na Kujawach. 5400-3650 p.n.e. Poznań: Polska Akademia Nauk, Instytut Archeologii i Etnologii.

Czerniak L., Kośko A.

1993 Z badań nad geneza rozwoju i systematyka kultury pucharów lejkowatych na Kujawach. Poznań: Uniwersytet im. Adama Mickiewicza.

Domańska L.

1995 Geneza krzemieniarstwa kultury pucharów lejkowatych na Kujawach. Łódź: Katedra Archeologii Uniwersytetu Lódzkiego.

Gabałówna L.

1970 Wyniki analizy C-14 węgli drzewnych z cmentarzyska kultury pucharów lejkowatych na stanowisku 1 w Sarnowie - z grobowca 8 i niektóre problemy z nimi związane (Infor-

\footnotetext{
${ }^{80}$ Probabilistyczny charakter dat, wpływ zróżnicowanych czynników na uzyskiwane wyniki, mała liczba oznaczeń oraz terytorialny rozkład dat z wyraźną preferencją Kujaw i ziemi chełmińskiej.

${ }^{81}$ Z perspektywy Niżu Polskiego materiały kujawskiej fazy I (sarnowskie), IIA (np. Inowrocław 95) i IIB (typ Podgaj-Przybranówek-Boguszewo) i wszelkie ich konfiguracje mieszane.

${ }^{82} \mathrm{Nie}$ wyłączając terenów pozaniżowych (np. Polski południowo-wschodniej), na których np. zdobienia o cechach wczesnych (np. w typie Podgaj-Przybranówek-Boguszewo) są spotykane.
} 
macja wstępna). Prace $i$ Materiały Muzeum Archeologicznego i Etnograficznego $w$ Łodzi. Seria Archeologiczna, 17, s. 77-91.

Gaerte W.

1927

Die steinzeitliche Keramik Ostpreussens. Königsberg: Gräfe Und Unzer.

Galiński T.

1997

Mezolit Europy. Szczecin: Drukarnia ZAPOL.

Galiński T.

2005 Nowe materiały tzw. fazy wczesnopucharowej osadnictwa protoneolitycznego na Pomorzu. Folia Praehistorica Posnaniensia, 13/14, s. 71-90.

Galiński T.

2012 Kultura protoneolityczna na Pomorzu w świetle najnowszych badań w Tanowie. Archeologia Polski, 57(1-2), s. 79-112.

Grygiel R.

1986 The household cluster as a fundamental social unit of the Lengyel Culture in the Polish Lowlands. Prace i Materiaty Muzeum Archeologicznego $i$ Etnograficznego $w$ Łodzi. Seria Archeologiczna, 31, s. 41-334.

Grygiel R.

2008 Neolit i początki epoki brązu w rejonie Brześcia Kujawskiego i Osłonek, t. II, Środkowy neolit - grupa brzesko-kujawska kultury lendzielskiej. Łódź: Fundacja Badań Archeologicznych Imienia Profesora Konrada Jażdżewskiego.

Gumiński W.

2011 Importy i naśladownictwa ceramiki kultury brzesko-kujawskiej i kultury pucharów lejkowatych na paraneolitycznym stanowisku kultury Zedmar - Szczepanki na Mazurach. W: U. Stankiewicz, A. Wawrusiewicz (red.), Na rubieży kultur. Badania nad okresem neolitu i wczesna epoka brazu (s. 149-160). Białystok: Muzeum Podlaskie w Białymstoku.

Jankowska D.

1980 Kultura pucharów lejkowatych na Pomorzu Środkowym. Poznań: Uniwersytet im. Adama Mickiewicza.

Jażdżewski K.

1936 Kultura puharów lejkowatych w Polsce zachodniej i środkowej. Poznań: Polskie Towarzystwo Prehistoryczne.

Jażdżewski K.

1970 Wzajemny stosunek do siebie elementów północnych, południowych i zachodnich w obrębie kultury pucharów lejkowatych. Prace i Materiały Muzeum Archeologicznego i Etnograficznego w Łodzi. Seria Archeologiczna, 17, s. 49-76.

Kabaciński J., Terberger T.

2009 From Late Hunter-fishers to Early Farmers on the Pomeranian Coast. Now research at Dąbki 9. W: J.M. Burdukiewicz, K. Cyrek, P. Dyczek, K. Szymczak (red.), Understanding the Past. Papers offered to Stefan K. Kozłowski (s. 165-184). Warszawa: Ośrodek Badań nad Antykiem Europy Południowo-Wschodniej, Uniwersytet Warszawski.

Kirkowski R.

1994 Kultura ceramiki wstęgowej rytej na ziemi chełmińskiej. Zarys systematyki chronologiczno-genetycznej. W: L. Czerniak (red.), Neolit i początki epoki brązu na ziemi chetmińskiej (s. 57-99). Grudziądz: Muzeum w Grudziądzu, Instytut Archeologii i Etnologii Uniwersytetu Mikołaja Kopernika.

Kirkowski R., Kukawka S.

1990 Boguszewo, gmina Gruta, województwo toruńskie, stanowisko 43b, obiekty 11 i 32. W:

D. Jankowska (red.), Z badań nad chronologia absolutna stanowisk neolitycznych z zie- 
mi chetmińskiej (s. 26-31). Toruń: Wojewódzki Ośrodek Ochrony Środowiska Kulturowego w Toruniu, Instytut Archeologii i Etnologii Uniwersytetu Mikołaja Kopernika.

Kirkowski R., Sosnowski W.

1994 Kultura późnej ceramiki wstęgowej na ziemi chełmińskiej, W: L. Czerniak (red.), Neolit i poczatki epoki brąu na ziemi chetmińskiej (s. 115-133). Grudziądz: Muzeum w Grudziądzu, Instytut Archeologii i Etnologii Uniwersytetu Mikołaja Kopernika.

Kośko A.

1981 Udziat poludniowo-wschodnioeuropejskich wzorców kulturowych w rozwoju niżowych spoteczeństw kultury pucharów lejkowatych. Grupa mątewska. Poznań: Uniwersytet im. Adama Mickiewicza.

Kozicka M.

2012 Chronologia kultury Zedmar na podstawie dat radioweglowych. [Maszynopis przechowywany w Instytucie Archeologii UMK w Toruniu].

Kukawka S.

1991 Kultura pucharów lejkowatych na ziemi chetmińskiej $w$ świetle źródet ceramicznych.

Torun: Towarzystwo Naukowe w Toruniu.

Kukawka S.

1994 Kultura pucharów lejkowatych na ziemi chełmińskiej - geneza i początkowe etapy rozwoju. W: L. Czerniak (red.), Neolit i początki epoki brąu na ziemi chetmińskiej (s. 161-173). Grudziądz: Muzeum w Grudziądzu, Instytut Archeologii i Etnologii Uniwersytetu Mikołaja Kopernika.

Kukawka S.

1997 Na rubieży środkowoeuropejskiego świata wczesnorolniczego. Toruń: Uniwersytet Mikołaja Kopernika.

Kukawka S.

2000 Zaludnienie i zmiany środowiska naturalnego w neolicie wyżyn lessowych (uwagi krytyczne). Archeologia Polski, 45(1-2), s. 99-109.

Kukawka S.

2010 Subneolit pólnocno-wschodnoeuropejski na Niżu Polskim. Toruń: Uniwersytet Mikołaja Kopernika.

Kukawka S.

2011 Kultura Narva i kultura ceramiki grzebykowej w Polsce północno-wschodniej. W:

U. Stankiewicz, A. Wawrusiewicz (red.), Na rubieży kultur. Badania nad okresem neolitu i wczesna epoka brazu (s. 69-75). Białystok: Muzeum Podlaskie w Białymstoku.

Kukawka S.

2012 Ceramika naczyniowa kultury pucharów lejkowatych ze stanowiska 4 w Starych Marzach, gm. Dragacz, woj. kujawsko-pomorskie. Acta Universitatis Nicolai Copernici. Archeologia, 32, s. 201-228.

Kukawka S., Małecka-Kukawka J., Wawrzykowska B.

2002 Wczesny i środkowy neolit na ziemi chełmińskiej. W: B. Wawrzykowska (red.), Archeologia toruńska. Historia i teraźniejszość (s. 91-107). Toruń: Muzeum Okręgowe w Toruniu.

Kurzyk K.

2013 Kultura amfor kulistych na ziemi chełmińskiej. [Maszynopis rozprawy doktorskiej przechowywany na UMK w Toruniu, Toruń].

Loze I.А. (Лозе, И.А.)

1988 Поселения каменного века лубанской низины. Мезолит, ранный и средний неолит. Riga: Zinatne. 
Małecka-Kukawka J.

1992 Krzemieniarstwo społeczności wczesnorolniczych ziemi chetmińskiej (2. połowa VI-IV tysiąclecie p.n.e.). Toruń: Uniwersytet Mikołaja Kopernika.

Nowak M.

1996 Ceramika kultury pucharów lejkowatych ze stanowiska 1 w Kawczycach. Kraków: Instytut Archeologii Uniwersytetu Jagiellońskiego.

Nowak M.

2009 Drugi etap neolityzacji ziem polskich. Kraków: Instytut Archeologii Uniwersytetu Jagiellońskiego.

Papiernik P.

2012 Sprawozdanie z badań wykopaliskowych na stanowisku 20 w Redeczu Krukowym, pow. włocławski, woj. kujawsko-pomorskie. Prace i Materiały Muzeum Archeologicznego i Etnograficznego w Eodzi. Seria Archeologiczna, 45(2010-2012), s. 221-238.

Prinke D.

1988 Środkowoneolityczne zalążki procesów synkretyzacji kultury pucharów lejkowatych na Kujawach. W: A. Cofta-Broniewska (red.), Kontakty pradziejowych społeczeństw Kujaw z innymi ludami Europy (s. 93-105) Inowrocław: Urząd Miejski w Inowrocławiu.

Rybicka M.

2004 Kultura pucharów lejkowatych na Pojezierzu Gostynińskim. Chronologia-osadnictwogospodarka. Łęczyca: Muzeum w Łęczycy.

Rybicka M.

2011 Przyczynek do badań nad datowaniem wczesnych faz kultury pucharów lejkowatych na

Niżu Polski. Materiaty i Sprawozdania Rzeszowskiego Ośrodka Archeologicznego, 32, s. 231-237.

Rzepecki S.

2004 Spoleczności środkowoneolitycznej kultury pucharów lejkowatych na Kujawach. Poznań: Wydawnictwo Poznańskie.

Rzepecki S.

2011 Studia i materiały nad najdawniejszymi dziejami Równiny Gorzowskiej. Osady i cmentarzyska kultury pucharów lejkowatych na stanowiskach Jastrzębiec 4 i Renice 5-6. Poznań: Wydawnictwo Poznańskie.

Szmyt M.

1992 Łojewo, gm. Inowrocław, woj. bydgoskie, stan. 35, osiedle z fazy wczesnowióreckiej kultury pucharów lejkowatych (z badań nad genezą i systematyką kultury pucharów lejkowatych na Kujawach). Sprawozdania Archeologiczne, 44, s. 49-98.

Szmyt M.

1996 Spoteczności kultury amfor kulistych na Kujawach. Poznań: Uniwersytet im. Adama Mickiewicza.

Wawrusiewicz A.

2011 Okres neolitu i wczesnej epoki brązu na Podlasiu. Stan i perspektywy badań. W: U. Stankiewicz, A. Wawrusiewicz (red.), Na rubieży kultur. Badania nad okresem neolitu i wczesna epoka brazu (s. 13-36). Białystok: Muzeum Podlaskie w Białymstoku.

Wierzbicki J.

1999 Lupawski mikroregion osadniczy ludności kultury pucharów lejkowatych. Poznań: Uniwersytet im. Adama Mickiewicza.

Wierzbicki J.

2013 Wielka kolonizacja. Społeczności kultury pucharów lejkowatych w dorzeczu środkowej Warty: koniec V-pot. III tys. BC. Poznań: Stowarzyszenie Naukowe Archeologów Polskich, Oddział w Poznaniu. 
Wiślański T.

1973 Ze studiów nad genezą kultury pucharów lejkowatych. Archeologia Polski, 18(1), s. $91-126$.

Wiślański T.

1979 Kształtowanie się miejscowych kultur rolniczo-hodowlanych. Plemiona kultury pucharów lejkowatych. W: W. Hensel, T. Wiślański (red.), Prahistoria ziem polskich, t. II, Neolit (s. 165-260). Wrocław-Warszawa-Kraków-Gdańsk: Zakład Narodowy im. Ossolińskich.

\section{BEGINNINGS OF THE FUNNEL BEAKER CULTURE IN THE POLISH PLAIN}

\section{Su m mary}

While discussing the shaping of the Funnel Beaker culture (hereinafter referred to as TRB) in the Polish Plain it appears essential to determine dating of its beginnings. As yet, as the earliest date obtained was assumed the one from Sarnowo 1, from beneath grave 8 (Bakker, Vogel and Wiślański 1969; Gabałówna 1970). Although there were archaeologists who looked at it sceptically (e.g. Gabałówna 1970; Wiślański 1979), it was accepted by majority of researchers of the Plain (Czerniak 1980, 1994; Czerniak and Kośko 1993; Jażdżewski 1970; Kośko 1981; Kukawka 1991; Rzepecki 2004). In recent years, its credibility was undermined by M. Nowak (2009). With publication of his book, numerous new radiocarbon dates of the Sarnowo type materials appeared, causing the date from Sarnowo to be rejected (Papiernik 2012; Rybicka 2011; Rzepecki 2011) and the beginnings of the discussed culture to be re-dated to about 4000 years BC (Nowak 2009) or slightly earlier, i.e. approximately around 4200/4100 years BC (the dates from Chełmno land - Kukawka 2010).

Accepting the "short" chronology implicates significant interpretative consequences. First of all, TRB, distinguished on the basis of pottery, from its very beginnings substantially varied in the Polish Plain. According to collected evidence, two distinct stylistic trends could be named: Sarnowo-Łącko-Strzelce-Krzyżanna type (TRB-s.1 as Rzepecki 2004) and the Podgaj-Przybranówek-Boguszewo type (Czerniak and Kośko 1993; Kukawka 1997). Presumably, there might be various intermediate stylistic trend as well. Perhaps, TRB appearing in a littoral zone at that time was already a separate trend (the Łupawa group, Tanowo, Dąbki - Galiński 2005, 2012; Jankowska 1980; Kabaciński and Terberger 2009; Wierzbicki 1999).

Rejection of the date from Sarnowo must result in the adoption of another conclusion, namely dismissing certain genetic interpretations concerning the appearance of TRB in the Polish Plain (e.g. Czerniak 1994; Czerniak and Kośko 1993; Kośko 1981; Rzepecki 2004).

Another assumption that should be rejected is the one suggesting that TRB at its very beginnings occupied sandy soils, and occupation of the ecumene formerly occupied by the Danubian cultures was secondary. From the very beginning, TRB was a phenomenon present in various environs, and its origins should be even associated with heavy soils (ecumene of the Danubian cultures).

There are many indications that the origins of TRB coincided with the disappearance of the Brześć Kujawski group, dated by R. Grygiel, on the basis of the analysis of radiocarbon dates, to 
about 4000 years BC (Grygiel 2008), both phenomena (disappearance of the Brześć Kujawski group and the beginnings of TRB) therefore happening in a period of significant environmental and climatic changes taking place around the Atlantic-Subboreal transition.

Potential local population and cultural substrate of the forming TRB could have been either communities of the Brześć Kujawski or Jordanów groups, or mesolithic or subneolithic ones. However, the mesolithic concept (e.g. Nowak 2009; Wiślański 1979) must be at least temporarily rejected, and that is for several reasons. The principal one is the lack of convincing evidence of the existence of the mesolithic settlement between enclaves of the Brześć Kujawski group in the last quarter of the fifth millennium BC. This hypothesis is also weakened by variable-environmental nature of settlement, suggesting rather that the ancestors of TRB population had had agrarian experience lasting for many generations. Finally, this Mesolithic concept is not reflected by characteristics of the most significant categories of artefacts - pottery and flint. They also do not approve of a significant influence of the Brześć Kujawski and Jordanów groups traditions. Observations from Chełmno land, on the other hand, suggest that although subneolithic communities participated in the formation of TRB from its earliest phase, they did not constitute a population substrate in its dawn (Kukawka 1997, 2010).

Distingushing TRB (including its territorial groups and phases of development) is based on contemporary choice of particular kind of pottery. Discussing the genesis and development (economy, graves, settlements, etc.) of an archaeological culture distinguished as such, one assumes that observed variability of pottery characteristics reflects, to some extent, the real prehistoric cultural diversity. While rejecting such an axiom, the search of TRB genesis will become easy and will lead back to the archaeology of the early twentieth century, when the culture was introduced into archaeology.

Many features of the earliest TRB pottery in the Polish Plain reflects relationships with the post-Linear groups. The use of grog temper, leaning ceramic mass, refers to the Lengyel-Polgar groups in Malopolska and to the Malice culture. It should also be noted that such a temper occurs in pottery of the late phases of the Brześć Kujawski group. Many features of ornamentation refer exactly to the post-Linear cultures, including rare ornaments, incised decorative motifs. or domination of external decorations under an edge of a rim. Special attention should be paid to the specific ornamentation of bodies, characteristic for so-called Podgaj-Przybranówek-Boguszewo type, and identified as Jordanów-Schussenriede influence (by Czerniak and Kośko, 1993). Almost all forms of early TRB vessels, including a funnel beaker, could be derived from the neighbouring postLinear cultures, though obviously the list of potential "donors" is much wider.

When analysing pottery of early TRB in the Polish Plain, it might be assumed that it represents a variant (maybe a bit depleted) of to the post-Linear groups; its flint working clearly refering to theirs (e.g. Lech and Domańska 1995; Małecka-Kukawka 1992; Młynarczyk 1981). Hence, seeing early TRB as a separate entity may be exaggeration determined by historical circumstances. This has been influenced by an early distinguishing of TRB as a separate archaeological cultural entity, and deeply-rooted (but shared also recently) views on its origins connected with a huntergathering population substrate and including it into a group of northern cultures, as opposite with respect to the southern Danubian groups. Considerable impact on its distinguishing has also had the date from Sarnowo and assumed parallel development with the Brześć Kujawski group, as well as inhabiting distinct ecological niches. Significant differences with respect to the Brześć Kujawski group indeed have also been noted (visible in pottery, characteristics of settlements, traces of dwellings, graves, etc.). 
It would be difficult to estimate the share of the local Brześć Kujawski group population in the formation of TRB. On the one hand, clearly seen is technological differentiation of pottery in both cultures, on the other grog temper has been noticed in vessels of the Brześć Kujawski group, while grit temper at some sites of early TRB. Certainly, despite the post-Linear communities there were also other groups involved in shaping of TRB in the Polish Plain. Indicating them from the perspective of the pottery analysis will not be easy. Perhaps, attention should be paid to some western influence, the phenomenon reflected in megalithism. Differentiation of pottery from the earliest sites, so far linked to Kujawy phases I, IIA and IIB seems to suggest far more complex course of events.

The other problematic issues concern recognition of this early period and the possibility to estimate the synchronicity of such diverse materials from the very beginnings of TRB. A good example of a dynamics of events is the situation observed in the north-eastern part of the Polish Plain. The inclusion of local Subneolithic groups into a new network of information exchange just after the appearance of TRB has been observed there (Kukawka 2010). Re-dating the TRB beginnings to about $4200 / 4100$ years BC blurs the previous image. The nature and lack of radiocarbon dates on the one hand, stylistic diversity of the early materials on the other, leave the questions regarding the chronological and spatial origins of TRB unanswered.

Translated by Lucyna Leśniak 